Clapham, A., Gaeta, P. eds. (2014) The Oxford Handbook of International Law in Armed Conflict. Oxford University Press.

Dinstein, Y. (2016) The Conduct of Hostilities under the Law of International Armed Conflict. 3rd edition, Cambridge University Press.

Solis, G. (2016) The Law of Armed Conflict: International Humanitarian Law in War. 2nd edition, Cambridge University Press.

\title{
International Organizations
}

The term international organization is most frequently associated with intergovernmental organizations, such as the United Nations (UN), the World Trade Organization, or the International Labour Organization. International organizations are generally comprised of sovereign states, although other entities can also apply to become members. They are, by their nature, multilateral. The International Law Commission defines an international organization as an "organization established by a treaty or other instrument governed by international law and possessing its own international legal personality" (ILC 2011). It is important to distinguish between intergovernmental organizations, which are the focus of this entry, and international non-governmental organizations, which are not established by intergovernmental agreement, are non-profit in nature and must adhere to the principle of non-interference in the internal affairs of states (Willets 2001). The International Committee of the Red Cross has a unique legal status, similar to that of intergovernmental organizations, such as the UN, while not being intergovernmental in nature.

International humanitarian organizations including the UN and the International Organization for Migration, which became a "Related Organization" of the UN in 2016, are generally well funded. This is largely because most donors continue to prefer to channel aid through these organizations, rather than giving it directly to other implementing organizations. This is because intergovernmental organizations are perceived as having greater capacity to manage large volumes of funds, and greater knowledge and expertise. In 2016, for example, 60 percent of all direct government humanitarian funding went to multilateral organizations. In contrast, non-governmental organizations received just 20 percent of direct government funding (Development Initiatives 2018).

International humanitarian organizations adopt different approaches to emergency and aid, and are subject to different mandates and restrictions. The $\mathrm{UN}$ is exempt from some key international legislation governing humanitarian 
relief operations. For example, humanitarian operations that are undertaken as a result of a United Nations Security Council (UNSC) Resolution are exempt from requiring consent from the parties involved. The UNSC "may adopt binding measures requiring parties to an armed conflict, and other relevant states, to consent to humanitarian relief operations or impose such operations on parties" (Akande and Gillard 2016: 18). Syria is an example of this: UNSC Resolution 2165 (2014) constituted a binding decision that UN humanitarian agencies and their implementing partners were authorized to provide humanitarian relief to conflict-affected populations. In this case, consent from the parties to the armed conflict was not required (Akande and Gillard 2016).

The UN often uses integrated missions in crisis-affected countries. However, at least some degree of political consensus is required for this approach to work. Moreover, when engaging in peace-keeping and peace-building missions, their legitimacy to coordinate humanitarian response may be compromised "as they are bringing humanitarian response within the all-encompassing strategy of stabilization" (DARA 2013: 5).

Humanitarian international organizations also face political limitations when it comes to humanitarian response. In Syria, for instance, the UN can only operate within the Syrian government's mandate and with its consent. The UN's presence in Damascus and its cooperation with the government have led to distrust among partners in opposition areas. This has had a negative impact on the organization's ability to deliver an effective humanitarian response (Independent Commission for Aid Impact 2018).

Despite efforts to improve coordination within the UN system, challenges persist. Agencies often compete rather than collaborate. There are instances of different agencies running parallel efforts, an example being during the early years of the Syrian refugee crisis, when agencies failed to coordinate their response (Mansour 2017; Kelley 2017).

A number of UN agencies increasingly "outsource" their work to local contractors and organizations. This reduces contact between those providing assistance and crisis-affected communities. Contact is also an issue in relation to understanding the needs of local populations and in terms of taking local context into account. Although some progress has been made, further efforts are required in this regard (DARA 2013).

International organizations have much to offer in terms of humanitarian response. However, continued efforts are needed to address some of the challenges outlined here and to maximize the effectiveness of their engagement in crisis-affected contexts.

\section{Anna Louise Strachan}




\section{References}

Akande, D., Gillard, E.C. (2016) Oxford Guidance on the Law Relating to Humanitarian Relief Operations in Situations of Armed Conflict. Oxford Institute for Ethics, Law and Armed Conflict.

DARA (2013) Now or Never: Making Humanitarian Aid More Effective. DARA.

Development Initiatives (2018) Global Humanitarian Assistance Report-2018. devinit. org.

Independent Commission for Aid Impact (2018) The UK's Humanitarian Support to Syria: A Performance Review. https://icai.independent.gov.uk/.

ICL (International Law Commission) (2011) Draft Articles on the Responsibility of International Organizations. Yearbook of the International Law Commission, II.

Kelley, N. (2017) Responding to a Refugee Influx: Lessons from Lebanon. Journal on Migration and Human Security, 5(1): 82-104.

Mansour, K. (2017) UN Humanitarian Coordination in Lebanon: The Consequences of Excluding Syrian Actors. Chatham House.

Willets, P. (2001) Transnational Actors and International Organizations in Global Politics. In: Baylis, J.B., Smith, S. eds. The Globalisation of World Politics. 2nd edition. Oxford University Press.

\section{Livelihoods}

In the humanitarian world, livelihoods are activities that allow people to secure the basic necessities of life, such as food, water, shelter and clothing (UNHCR 2014: 1). The term has historically drawn special attention as it is widely employed by non-governmental organizations (NGOs) and United Nations agencies dealing with development and relief in rural and urban environments. The frequently protracted nature of crises produced by human-made conflict or natural disasters has ended up placing greater emphasis on refugee capacity to develop coping mechanisms and self-reliance, which have now gained great momentum in international debates. In fact, during the 1960 and 1970s the strategy of targeting refugees around the world by humanitarian livelihoods-programming changed from the care and maintenance of refugees to a self-reliance formula. In the same vein, the language of "resilient" (Reid 2012) or "sustainable" livelihoods (Chambers and Conway 1992) has placed further responsibility to survive and thrive on the beneficiaries themselves, based on 